\title{
ENTRE A HISTÓRIA E A LITERATURA: A IDENTIDADE NACIONAL EM LIMA BARRETO*
}

\author{
Between History and Literature: The national identity \\ in Lima Barreto
}

\author{
Cristiane da Silveira**
}

\begin{abstract}
O homem, por intermédio da arte, não fica adstrito aos preceitos $e$ preconceitos de seu tempo, de seu nascimento, de sua pátria, de sua raça; ele vai além disso, mais longe que pode, para alcançar a vida total no universo e incorporar sua vida na do mundo. Lima Barreto
\end{abstract}

\begin{abstract}
RESUMO
Este artigo tem por objetivo refletir sobre os cruzamentos entre a literatura e a história para a construção do conhecimento histórico, buscando na primeira um novo olhar sobre a identidade nacional logo após a instauração do regime republicano no Brasil. Para nossas análises privilegiamos a produção literária de Lima Barreto, a qual possibilitounos pensar a formação da identidade nacional a partir das várias situações vivenciadas pelos sujeitos marginais da República, ou seja, os negros, os mulatos, homens e mulheres pobres. Identidade essa pautada no sentimento de pertencimento ao país e não por meio do discurso homogeneizador veiculado pelas elites e os governantes, mas da sua busca pela afirmação social.
\end{abstract}

Palavras-chave: literatura; identidade nacional; república.

\begin{abstract}
This article intends to reflect about the crossing between literature and history to build historic knowledge, searching in the first one a new look about the national identity immediately after the beginning of the

* $\quad$ Essa discussão faz parte das análises realizadas na Dissertação de Mestrado defendida no Programa de Pós-Graduação em História da Universidade Federal de Uberlândia, intitulada: O alvorecer da República sob o olhar interpretativo de Lima Barreto, orientada pela prof ${ }^{\mathrm{a}}$. Dr ${ }^{\mathrm{a}}$ Christina da Silva Roquette

** Mestre em História pela Universidade Federal de Uberlândia.
\end{abstract} Lopreato. 
republican regime in Brazil. For our analyses we privileged the literary production of Lima Barreto, which gave us the possibility of thinking about the formation of national identity from several situations lived by marginal people, in other words, the black, the half-breed, poor people. This identity was made under the feeling of belonging to a country and not by the homogenized speech made by the elite and authorities, but its search for social affirmation.

Key-words: literature; national identity; republic.

Reviver o passado significa buscar vestígios que trazem à tona um "tempo perdido". O passado não pode ser re-construído na sua totalidade, pois ao revivê-lo o tornamos diferente e o carregamos de novas significações e interpretações. O passado é re-construído pelo olhar de quem viveu o momento buscado, não apenas pela oralidade, mas também por documentos escritos, oficiais ou ficcionais. Esses documentos muitas vezes relatam ou deixam transparecer os sentimentos mais íntimos que, em algum momento, se fizeram presentes na realidade e na imaginação dos agentes históricos responsáveis pela sua construção.

Tendo em vista a dinâmica da re-construção do passado, este artigo busca refletir sobre um caminho possível para a reflexão da identidade nacional por meio das narrativas literárias de Lima Barreto, nas primeiras décadas da República no Brasil, mais especificamente de 1904 a 1920. O texto está dividido em duas partes: na primeira há uma breve discussão sobre as possibilidades de cruzamentos e os limites entre a literatura e a história, entendendo que essa questão ainda carece de muita discussão. A seguir, procuramos, por meio das narrativas literárias de Lima Barreto, construir um novo olhar sobre a formação da identidade brasileira e a vivência dos marginais da recém-criada República brasileira em busca de afirmação social, por meio das manifestações dos mais íntimos sentimentos desses sujeitos marginais que incorporaram os ideais apregoados pelos gestores da República de maneira muito particular. 


\section{História e Literatura: encontros e desencontros}

As histórias de Clara dos Anjos, Policarpo Quaresma, Isaías Caminha, Cassi Jones, Gonzaga e Sá, entre outros, todos personagens de Lima Barreto, permitem-nos (re)construir a trajetória de pessoas que lutaram pelos seus ideais e interesses experimentando uma nova forma de construção da identidade nacional brasileira. As histórias “anônimas” desses personagens literários foram, durante muito tempo, desconsideradas pela historiografia brasileira, pois esta não as reconhecia como testemunhos históricos. Nos dias atuais, o debate sobre aos cruzamentos entre a história e a literatura é ainda candente. Veremos a seguir alguns pontos.

Ao se eleger a produção literária como documento histórico, deparamo-nos com a discussão da literatura como fonte histórica, visto que esse material, ao transitar entre a ficção e a realidade, permite-nos uma re-leitura dos aspectos e das semelhanças da realidade vivida numa temporalidade passada, mas também gera muita discussão sobre sua validade como fonte para a pesquisa histórica.

A possibilidade da utilização da literatura como documento histórico foi possível graças ao debate historiográfico que se seguiu a partir dos anos 1960, problematizando novos temas e objetos, inserindo-os no campo das paixões e não somente das racionalidades, buscando análises que privilegiavam os sentimentos e as sensibilidades na re-construção da história.

A pesquisa histórica que procura trazer à tona os sentimentos, as sensibilidades, as paixões dos sujeitos em determinadas épocas, tem como centro das preocupações as relações de poder que se fazem por meio dos jogos políticos. O plano político ao qual esta história se refere não está presente apenas nas relações travadas pelo Estado, mas nos diferentes âmbitos da vivência social, pois o político "não constitui um setor separado: é uma modalidade da prática social"1 que se concretiza no cotidiano e é reelaborado de acordo com as expectativas e experiências pessoais. Sendo assim, os registros históricos não ficam meramente circunscritos às práticas oficiais.

1 RÉMOND, René. Do político. In: (Org.). Por uma história política. [S.l.]: UFRJ FGV, 1996. p. 35-36. 
Dentro dessa nova perspectiva historiográfica, o processo de construção do conhecimento em história começa a ser entendido como um movimento dinâmico, que se faz em meio ao eterno (re-)pensar do homem sobre o antes e o agora, tentando, a partir de suas inquietações, formular outras interpretações sobre essa temporalidade.

Em decorrência dessa concepção, cria-se o conhecimento sobre o passado com indagações que partem do presente, em função da necessidade de se conhecer a história por meio do estudo de visões ainda pouco exploradas. Ao procurar por explicações outras, que não as consagradas, o historiador se deparou, entre outras fontes, como a literatura.

Se hoje percebemos a preocupação de vários intelectuais que se dedicam aos estudos sobre as fronteiras - que significam obstáculos à comunicação, mas também regiões de encontro - entre a história e a ficção, em muitos momentos verificamos uma ligação muito próxima entre ambas, cujas fronteiras foram sendo construídas ao longo do tempo. $\mathrm{Na}$ Grécia Antiga, por exemplo:

Encontramos uma cultura na qual a distinção entre história e ficção era autoconsciente (do que deriva nossa própria consciência da distinção) mas também uma cultura na qual (em comparação com o Ocidente dos séculos XIX e XX) a fronteira era mais aberta e/ou colocada em lugar diferente. ${ }^{2}$

Já na “Idade Média, a fronteira entre história e ficção (seja nos casos das vidas dos santos, seja nos 'romances' de Artur e Carlos Magno) era extremamente aberta, tanto assim que é difícil localizá-la”. Diferentemente do que acontece com o Renascimento, no qual "vemos um aparente retorno aos padrões clássicos (...) Como no caso de Aristóteles, e seguindo Aristóteles, humanistas e outros fizeram distinções explícitas entre história e ficção". ${ }^{3}$ Assim, podemos perceber que hoje, herdeiros do Renascimento, buscamos por fronteiras mais abertas entre esses campos. ${ }^{4}$

2 BURKE, Peter. As fronteiras instáveis entre historia e ficção. In: Gêneros de fronteira: cruzamentos entre o histórico e o literário. Vários organizadores. São Paulo: Xamã, 1997. p. 107-115.

3 Id.

4 Burke faz uma análise da trajetória dos pensadores que se debruçaram sobre as fronteiras entre história e ficção, desde a Antiguidade até os dias atuais, ressaltando que o período atual foi o mais fértil, uma vez que essas fronteiras se reabriram para novas discussões. 
Questionar onde realmente estão os cruzamentos entre a história e o romance ficcional constitui-se tarefa complicada. No entanto, acreditamos que por meio da literatura o historiador possa alcançar uma distensão maior entre os limites de ambos e contribuir para a amplitude da construção histórica, privilegiando os sentimentos dos sujeitos que procuraram refletir sobre o momento vivido, a partir das possibilidades de vivências pessoais e de seus contemporâneos.

O cruzamento entre história e literatura possibilita uma maior flexibilidade para se pensar a história e os vários elementos constituintes de sua (re)construção, pois entendemos não existir uma única visão dos objetos em análise, mas perspectivas que podem apontar diferentes estilos de representação. Desse modo, somos instigados a procurar novos elementos para sua construção.

Neste sentido, torna-se importante destacar o fato de que a produção da obra literária está associada ao seu tempo, refletindo em suas narrativas angústias e sonhos de agentes sociais contemporâneos à sua criação e mesclando elementos de ficção e das possíveis realidades existentes no momento da criação literária. Dessa forma, a obra de ficção lida com ações sonhadas, com sentimentos compartilhados, com intermediação entre o real e as aspirações coletivas. A obra literária constitui-se, assim, parte do mundo, das criações humanas, e transforma-se em relato de um determinado contexto histórico-social. Por isso, "qualquer obra literária é evidência histórica objetivamente determinada - isto é, situada no processo histórico". ${ }^{5}$

Para Sevcenko, o estudo da literatura traz consigo nova possibilidade de análise do passado, por meio da fala dos não ajustados socialmente. A narrativa literária cria a possibilidade do vir a acontecer, dos sonhos que revelam outro cotidiano que não apenas o dos vencedores, faz alusão a sujeitos que reelaboram sua prática social e os transforma em realizadores de sua própria história, permitindo, finalmente, o conhecimento de uma realidade que não apenas a sacralizada pela história dos vencedores. ${ }^{6}$

A literatura (quer seja romances, crônicas ou contos) lida com o estudo do imaginário social, cuja manifestação se dá por meio de imagens e

5 CHALLOUB, Sidney; PEREIRA, Leonardo Lima. A história contada. Rio de Janeiro: Nova Fronteira, 1998. p. 7.

6 SEVCENKO, Nicolau. Literatura como missão. Tensões sociais e criação cultural na $1^{\text {a }}$ República. 2. ed. São Paulo: Brasiliense, 1993. p. 21. 
discursos, resultado do permanente campo de tensão entre os grupos, e neste embate os sujeitos conferem sentido e explicação ao mundo. Chartier ${ }^{7}$ compreende a representação como um instrumento de reconhecimento de um objeto ausente e de exibição de uma presença, nos quais permanece uma constante relação entre imagem presente e objeto ausente. A luta pela sobrevivência cotidiana confere lugar aos sujeitos e permite a divisão da sociedade em grupos, cujas práticas existem nas representações transpostas para a vivência dos sujeitos, por meio das falas, das práticas político-sociais e dos discursos elaborados pelos diferentes grupos sociais. As representações não são menos reais que as ações concretas, mas são a própria realidade, pois a ação não existe antes de ser pensada, imaginada na realidade dos sujeitos que a concebem e a amealham.

A literatura pertence ao campo das representações e cabe, pois, ao historiador reinterpretar o encontro entre os mundos dos textos e dos leitores, e como os leitores incorporam e se apropriam de diferentes formas dos textos em momentos históricos distintos. Os leitores, “com efeito, não se confrontam com textos abstratos, separados da materialidade: manejam objetos cujas organizações comandam a leitura, sua apreensão e compreensão partindo do texto lido". ${ }^{8}$

Para além dessa questão, é possível afirmar que a produção literária não é construída com vistas a um fim pré-determinado pelo autor, cuja escrita sugira antecipadamente esquemas de interpretação e de apropriação do texto pelo leitor. Ao contrário, somente o leitor poderá conceder à produção literária um fim. No entanto, é perceptível na relação leitor e texto, de acordo com De Decca, um fato estético:

Em que o leitor existe para além do texto, mas ao mesmo tempo traduz o próprio texto em sua existência cotidiana e em suas ações. Isto é, o leitor transfere o fato estético para o universo da historicidade, uma vez que ele, como sujeito da ação, pode imprimir forças às imagens literárias, traduzindo-as no sentido de sua própria vida. ${ }^{9}$

7 CHARTIER, Roger. O mundo como representação. Estudos Avançados, São Paulo, v. 11, n. $5,1991$.

8 Ibid., p. 178.

9 De DECCA, Edgard. Literatura, modernidade e história: o olhar do estrangeiro sobre o mundo colonial. In: LUNHARDDT, Jaques; PESAVENTO, Sandra Jataí (Orgs.). Discurso histórico e narrativa literária. Campinas: Unicamp, 1988. p. 70. 
A partir dessa compreensão, a obra literária amplia as possibilidades de abordagens históricas. Ao historiador não cabe ter como preocupação central a análise crítica direcionada à sua forma de construção literária, mas a lógica singular da narrativa literária, que se encontra fundada no momento de produção. Com isso, o que interessa ao historiador no texto literário:

não é (o seu) caráter manifestamente ficcional ou não determinado como testemunho histórico, mas a necessidade de destrinchar sempre a especificidade de cada testemunho. Assim, por exemplo, cabe ao historiador descobrir com igual afinco tanto as condições de produção de uma página de um livro de atas, o de um depoimento criminal, quanto os de um conto, de uma crônica e de uma peça literária. Cabe o mesmo interrogatório sobre as intenções do sujeito, sobre como este representa para si mesmo a relação entre aquilo que diz do real, cabe desvendar aquilo que o sujeito testemunha sem ter a intenção de fazê-lo, investigar as interpretações do autor, enfim, é preciso buscar a lógica social do texto. ${ }^{10}$

Há, na produção literária, um universo muito rico de vestígios para a interpretação de seu momento histórico que não se esgota na palavra escrita, mas transcende-a, rumando em direção ao campo das representações, as quais se fazem no cotidiano dos mais variados sujeitos. Todo testemunho histórico, independentemente de ser um documento oficial ou uma obra de arte, traz consigo significações que serão entendidas quando devidamente analisada sua relação com o contexto histórico no qual o objeto foi produzido, revelando as lutas que a vitória de determinado "projeto de cultura" deixaram cravadas, trazendo, assim, a representação de seu grupo social.

A obra de arte transforma seus valores de acordo com o tempo no qual está inserida, tendo, assim, diferentes significados para épocas posteriores à sua criação. O significado que o artista e os homens de determinado tempo lhe aferem é o resultado da cultura de seu tempo, sendo, com 
isso, a expressão dos jogos de tensão e as opções escolhidas pelo seu criador. ${ }^{11}$

No mundo da imaginação não existem barreiras, tanto para o escritor como para o leitor. Tudo é plausível de acontecimento: os sonhos se transformam em realidade quase palpável. Novas sensações são suscitadas no leitor, e este pode, por intermédio da leitura, ser instigado à transformação dos seus pensamentos mais íntimos.

Nesta perspectiva, é possível perceber que as narrativas literárias têm como característica a semelhança e as possibilidades de acontecimento do momento de sua produção. Por meio das análises realizadas por Stella Bresciani a respeito de Germaine de Staël, podemos entender as narrativas literárias sob uma perspectiva mais ampla, lembrando que Staël acredita que a obra de ficção seja um instrumento para a formação dos cidadãos para a república democrática francesa, pois:

Sua adequação ao regime político de liberdade residiria na forma da trama novelesca, onde tudo é ao mesmo tempo "inventado e imitado”, “onde nada é verdadeiro, onde tudo é verossímil”, onde a "pintura de nossos sentimentos habituais” parece dirigir-se diretamente ao leitor, falar dele, de sua vida e de desejos íntimos. ${ }^{12}$

Assim, abre-se a perspectiva de pensar as ficções literárias não como cópias da realidade, mas como possibilidades de acontecimento, as quais estão intimamente ligadas com os sentimentos e a imaginação de quem faz parte do momento de sua confecção. Assim, a criação literária não é cópia do momento da sua realização, mas tudo que é escrito torna-se, em certa medida, verossímil, ou seja, passível de acontecimento.

Dessa maneira, é possível privilegiar a literatura como importante elemento constituinte para a re-construção da história. Com a literatura, a

11 Argan, em a História da arte como história da cidade, refere-se mais precisamente à arquitetura, no entanto, acreditamos que suas análises são válidas para a obra de arte em geral, independentemente de ser um quadro, um romance, uma escultura ou um projeto arquitetônico. ARGAN, Giulio Carlo. História da arte como história da cidade. São Paulo: Martins Fontes, 1995. p. 24-25.

12 BRESCIANI, Maria Stella. O poder da imaginação: do foro íntimo aos costumes políticos. Germaine de Staël e as ficções literárias. In: SEIXAS, Jacy; BRESCIANI, Maria Stella; BREPOHL, Marion (Orgs.). Razão e paixão na política. Brasília: Universidade de Brasília, 2002. p. 42. 
possibilidade do acontecimento histórico é alargada, pois no mundo imaginário não existem regras sociais a serem cumpridas e as ações acontecem independentemente das vivências sociais do sujeito histórico real, tornando-se, portanto, campo fértil para dar vazão aos anseios mais íntimos dos sujeitos que, dessa forma, ampliam a dinâmica social vivida.

Para este estudo, buscamos construir, a partir das narrativas literárias de Lima Barreto, um novo olhar sobre a identidade brasileira, entendendo a literatura como um campo de conhecimento relevante de registro e fomento da história emergente.

\section{Identidade nacional em Lima Barreto: possibilidades que privilegiam os sentimentos e a solidariedade}

As histórias “anônimas” narradas por Lima Barreto permitem um olhar sobre a construção da identidade nacional brasileira voltada para as potencialidades dos sujeitos que caminhavam pelas ruas do Rio de Janeiro em busca de sua sobrevivência cotidiana, muitas vezes esquecidos pelo Poder Público. Discutir essas multiplicidades de experiências, em boa parte desconsideradas pelo governo e pelas elites, por significarem singularidades de um Brasil que se desejava esquecido, possibilita seguir um novo caminho para o entendimento da identidade brasileira.

Para trazermos à tona essa nova perspectiva de construção da identidade nacional, elegemos os romances de Lima Barreto como guia para o caminho a ser construído. Antes, porém, procuramos recuperar alguns aspectos da trajetória do escritor.

A vida do romancista Lima Barreto foi marcada pela tentativa constante de ultrapassar fronteiras, repensar atitudes e valores, refletir sobre a situação em que se encontrava grande parcela da população menos privilegiada economicamente no Brasil, durante o período da Primeira República. Entretanto, alguns pesquisadores procuraram explicar a obra de Lima Barreto apenas como resultante do ressentimento deste em relação à política de exclusão e preconceito contra a população marginalizada e por não ter conquistado o lugar desejado como grande escritor. Esse olhar acabou reduzindo, por muito tempo, o caráter combativo de sua literatura. 
Analisando os diários e romances de Lima Barreto, Beatriz Jaguaribe chama a atenção para a caracterização da obra de Lima Barreto feita por Joel Rufino como fruto de ressentimento. Ao fazer-se personagem de si mesmo, sem, no entanto, promover nenhuma mediação entre a realidade e a imaginação, pois Lima Barreto percebia o mundo ao seu redor apenas por esse (res)sentimento. Para Rufino, a vida do romancista foi uma grande seqüência de fracassos. Ao buscar sair desse modelo esquemático de interpretação da relação vivência/obra, em muitos momentos de sua reflexão Jaguaribe é pega pela mesma armadilha:

A escritura íntima de Lima Barreto revela a dialética do fracasso. A vida de Lima Barreto foi, com efeito, um sumário do "fracasso" do escritor de prosa realista, do crítico que articulava a literatura como documento social na missão reivindicatória de uma cidadania para os despossuídos da cidade. Se a escritura explicitamente ficcional dos romances almejava pichar o protesto nas fachadas acadêmicas da cidade letrada, a escritura íntima desdobra-se como um lamento e uma purgação da distância entre o que o Lima Barreto escritor desejava projetar e a resposta crítica que o meio social lhe propiciou. ${ }^{13}$

Para a autora, os escritos de Lima Barreto permanecem em dois campos de tensão: o que atinge o seu íntimo (diário) e o público (romance), mas o fracasso é revelado de modo amplo no primeiro. A punição recebida por Lima Barreto ao não se ajustar às regras impostas foi não conseguir alcançar seu sonhado lugar no meio intelectual.

No entanto, essas não-vitórias devem ser relativizadas, pois o momento não era para a exposição de pensamentos diferentes daqueles provenientes dos dirigentes da sociedade. Contudo, Lima tecia ácidas críticas contra eles. Ao atentarmos para a vida desse escritor, acreditamos que houve várias vitórias, como, por exemplo, ter conseguido publicar a maioria de seus romances, mesmo que a publicação não tenha lhe dado grande retorno financeiro. Além disso, ele foi um assíduo colaborador em jornais e revistas do Rio de Janeiro.

13 JAGUARIBE, Beatriz. Subjetividades urbanas em Pompéia, Machado e Lima Barreto. In: Fins de século: cidade e cultura no Rio de Janeiro: Rocco, 1998. p. 63. 
Se sua vida fosse constituída apenas por fracassos, sua inserção social não teria se realizado. Mesmo à revelia dos intelectuais, Lima conseguiu trazer à tona o relato dos sujeitos marginais e de sua insatisfação com os rumos tomados pela República. Pensou de maneira única na identidade desses marginais, mostrando-os como seres ativos em seu cotidiano, tarefa demasiadamente difícil. Lins aponta interessante reflexão sobre a obra de Lima Barreto:

Lima Barreto não combate em benefício próprio; os preconceitos e as injustiças despertam sua ira pelo que não são, e não pelo fato de atingirem a ele. Longe de ser - e só isto - um ressentido, ele é um lutador, um escritor consciente das desigualdades, das degradações de natureza ética e estética, um ser humano cheio de fervor, sonhando um mundo menos estúpido e clamando até a morte - sem meios-termos, sem frieza, assumindo posições claras, com truculência, com cólera - a sua verdade. (Grifo do autor) ${ }^{14}$

Essa análise proporciona uma visão mais abrangente da produção de Lima Barreto que não se fecha na vida do escritor e alcança um contexto social mais amplo, ou seja, o meio em que ele vivia. Ao produzir sua obra, Lima pensava não apenas em seus fracassos, mas na dinâmica social na qual grande parte da população era sacrificada em benefício de poucos. Seus romances procuraram trazer à tona uma reflexão sobre os caminhos tomados pela recém-criada República. É por meio da literatura que o escritor procurou chamar a atenção do público para a necessidade da reação do povo, para a construção de uma sociedade mais justa para todos. Com isso, seu interesse extrapolou sua vivência particular e buscou atingir o bemestar da sociedade em geral.

Ao se analisar a vida de Lima Barreto, ressaltamos a necessidade de se considerar a mediação entre as mazelas presentes em seu cotidiano, sua resistência diante delas e a busca pelo bem-estar geral. Não se pode negar que a cultura de exclusão muito contribuiu para seu desalento pessoal, fato este que foi criticado com ironia e irreverência. 
Ao analisar a produção de Lima, Nicolau Sevcenko chama a atenção para o fato de que Lima Barreto queria apenas dar vazão ao cotidiano que o oprimia, e assim "não estava preocupado em fornecer sonho ou analgésicos para as dores de seus personagens ou leitores", ${ }^{15}$ mas desmascarar a hipocrisia reinante, pois só assim os marginais se fariam ouvir. Procurou, então, dar voz às falas silenciadas pelo ideal de modernidade brasileira, que violava direitos e sonhos das classes populares.

Ao longo de sua vida, Lima Barreto refletiu profundamente sobre os problemas da nação brasileira. Tinha a forte convicção de que as instituições republicanas deveriam passar por profundas mudanças, principalmente com respeito à contenção do avanço da corrupção na burocracia. Ele julgava serem necessárias mudanças estruturais e funcionais no Estado, que, na maioria das vezes, contratava e promovia seus funcionários não de acordo com as necessidades reais, mas sim em troca de favores que beneficiavam amigos ou familiares. Essa troca de benesses era pautada sobretudo na cordialidade e não visava à melhoria social e econômica da coletividade. Essa dura realidade era presenciada por Lima em seu cotidiano na Secretaria de Guerra, ${ }^{16}$ onde trabalhava.

Na literatura produzida por Lima, o romancista construiu seu sonho de moralização da República, vivenciada pelo seu personagem Gonzaga e Sá, que reivindicou projetos políticos mais eficazes, que, certamente, passariam por um processo de transformação/revolução nas estruturas políticas, econômicas e sociais do Brasil. O escritor procurou mostrar, com a narrativa de seu personagem, que estes eram projetos utópicos, escritos em maiúsculo, talvez como forma de reafirmar o quanto a realidade republicana deixava a desejar. Assim, transformou as possibilidades reais em sonhos, pois naquela época a conjuntura político-social e econômica pouco permitia:

Quis ali, em segundos, organizar a minha República, erguer a minha Utopia, e, por instantes, vi resplandecer sobre a terra

15 SEVCENKO, op. cit., p. 193.

16 Em 27 de outubro de 1903 Lima Barreto foi nomeado amanuense da Secretaria de Guerra, e permaneceu no cargo por 16 anos. O trabalho na Secretaria lhe causava profundo desgosto, pois representava o ostracismo da administração pública, com seus desmandos e relações corrompidas que tanto Lima Barreto desprezava. 
dias de Bem, de Satisfação e Contentamento. Vi todas as faces humanas sem angústias, felizes, num baile! Tão depressa me veio tal sonho, tão depressa ele se desfez. (...) Tive um louco desejo de acabar com tudo; queria aquelas casas abaixo, aqueles jardins e aqueles veículos; queria a terra sem homem, sem a humanidade, já que eu não era feliz e sentia que ninguém o era ... Nada! Nada! ${ }^{17}$

Na fala do personagem, percebemos uma revolta que instiga a ação. Essa, por sua vez, revolucionaria todas as estruturas, pois representava 0 começo de uma nova vida para o país. Vida essa que deveria ter sido inaugurada com o advento da República no Brasil. A perspectiva da República de Lima Barreto procurava alcançar a população em geral, e não apenas as classes privilegiadas economicamente.

Lima Barreto morreu em 1 de novembro de 1922, já muito doente e por isso pouco conheceu da nova proposta de literatura que estava emergindo naquele ano, com a Semana de Arte Moderna, que introduziu pensamentos e posturas diferentes das até então defendidas pela elite intelectual brasileira. Essa nova perspectiva de arte rompia o abismo entre a literatura e a sociedade e se engajava no terreno da reflexão social.

Inconscientemente, Barreto foi um dos primeiros escritores a lançar a semente da mudança no meio intelectual em que viveu. Mesmo que, em seu tempo, tenha sido considerado um intelectual de pouco valor, manifestou sua insatisfação com a literatura até então produzida e, em sua obra, conseguiu romper com várias estruturas. Ao não se prender a nenhum préconceito e/ou escola literária, Barreto não impôs limites para sua imaginação-ação-reação.

Ação porque Lima Barreto utiliza sua escrita para construir uma nova visão sobre os marginais da Primeira República, que possibilita pensar a identidade brasileira por meio do resgate dos sentimentos dos cidadãos marginais. Neste sentido, ressaltamos que uma análise mais atenta de sua obra aponta para a possibilidade de considerá-lo como importante referência para se pensar a questão da identidade. Essa que não estaria por se fazer, mas encontrava-se presente nas ações de sujeitos que viviam a Repú-

17 BARRETO. Vida e morte de M. J. Gonzaga e Sá. São Paulo: Ática, 1997. p. 85. 
blica de um modo bastante particular e não nos moldes inspirados por outros países. Perseguir essa perspectiva na produção de Lima Barreto é um desafio, uma vez que em sua obra não explicita um projeto de interpretação do Brasil e suas novas relações com o advento da República. Mas isso não inviabiliza a possibilidade de considerá-lo como mais um intérprete do Brasil. Imaginação-reação porque é no campo da imaginação literária que vão se concretizar as realizações/(in)satisfações desses sujeitos marginais. Estes entram na literatura de Barreto inaugurando uma nova forma de fazer e pensar a arte literária brasileira. Ao longo da história literária do Brasil, a criação de Lima Barreto foi vista como uma obra de menor envergadura e mal acabada. Somente muitos anos após sua morte é que se processou uma crítica mais apurada sobre a real significação da produção do romancista para o entendimento das relações travadas no Brasil de seu tempo. Embora o reconhecimento de sua obra tenha sido tardio, Lima se firmou aos poucos, por etapas, como ressalta Andréa Saad Hossne:

É comum, sobretudo nos textos críticos das décadas de 1940 e 1950, Lima Barreto ser classificado como um "quase” grande escritor, que maior seria tais complexos, ressentimentos e amarguras, e sem o álcool a turvar-lhe a visão. / Na década de 1970, será justamente esse suposto vazamento da vida do autor em suas obras, o teor ácido e crítico que essa voz excluída lhes confere o que será valorizado. ${ }^{18}$

Tendo em vista a posição do autor na sociedade, passemos agora às reflexões sobre o período em análise e a obra de Lima Barreto. 


\section{Participação política na Primeira República: (des)encontros com a cidadania}

Com a proclamação da República no Brasil houve uma forte preocupação por parte da elite política e dos governantes em introduzir na sociedade brasileira o ideal de democracia e progresso. São exemplos dessa política em formar esse novo sujeito: a construção de monumentos em saudação à República, a criação de vários símbolos (a bandeira, o hino nacional) e a erupção de discursos que procuravam induzir, nos mais variados indivíduos, a fomentação de um novo imaginário social, pautado na noção de cidadania e identidade nacional.

Para a historiadora Márcia Regina Naxara, a segunda metade do século XIX e a passagem para o século XX foi um período privilegiado para a constituição e emergência do imaginário da identidade nacional brasileira. Nesse momento, consolidou-se a imagem do brasileiro como indolente, vadio, preguiçoso e não civilizado. Essas imagens foram construídas a fim de justificar a política de imigração do trabalhador europeu, pois o trabalhador negro foi colocado como incapaz de exercer o trabalho livre de forma eficiente. E assim, de acordo com Naxara:

Ao longo do tempo, foram inúmeros os registros dessa desqualificação e as queixas com relação aos elementos vistos e representados como "vadios” e "perigosos" que, desde sempre, perambulavam, primeiro pelas vilas e, mais tarde, pelas cidades, tirando o sossego dos chamados "homens bons" e empanando o encanto da vida "civilizada" das elites brasileiras, além de, freqüentemente, serem responsabilizados pelo atraso do país, tanto do ponto de vista cultural, como do ponto de vista material. ${ }^{19}$

Imagens fortes que persistem até os dias atuais. Para Naxara, a literatura produzida nessa época muito contribuiu para a consolidação dessas imagens e para o "descobrimento" do Brasil, muito especialmente o

19 NAXARA, Márcia Regina. A construção da identidade: um momento privilegiado. Revista Brasileira de História, São Paulo, v. 12, n. 23/24, set. 1991/ago. 1992, p. 181. 
personagem Jeca Tatu, de Monteiro Lobato. Na virada do século XIX/XX estavam presentes na sociedade discursos de democracia e a generalização da figura do trabalhador nacional, mas também a gestação da exclusão desses mesmos sujeitos como pertencentes à noção formada de identidade nacional brasileira.

Para forjar uma noção homogênea de identidade nacional muitas foram as singularidades/subjetividades nacionais silenciadas ao longo da história do Brasil, uma vez que fomos levados a pensar na identidade nacional como algo que unia todos os cidadãos num único modelo. O discurso de construção da identidade nacional presente nesse momento caminha contra o passado e a própria realidade vivida no Brasil, cuja multiplicidade cultural e étnica formou o ser brasileiro, e esse não era apenas branco, como queria as elites, mas uma mistura de nacionalidades e culturas.

Mas sendo o brasileiro fruto da mistura de múltiplas raças, línguas e cultura, em que medida realmente houve a identificação dos mais variados sujeitos na formação do ser brasileiro? Como tratar realidades plurais e fisionomias múltiplas num único discurso homogeneizador de identidade nacional/unidade? Como pensar experiências de sujeitos tão diferentes como sendo constituintes de uma única realidade? Em conseqüência dessa situação, a constituição da identidade do brasileiro foi contraditória, uma vez que não houve abertura de espaço para todos os tipos sociais.

Ao refletir sobre a identidade francesa e seu processo de formação, Yves Déloye oferece importantes contribuições para se pensar sobre essa difícil questão a ser enfrentada. Para o autor, a identidade nacional é uma construção histórica que permanece em constante mutação, e não uma noção fechada, enclausurada no imaginário coletivo ou individualmente. Portanto,

Longe de ser um dado que se impõe aos atores sociais, a identidade nacional constitui, ao contrário, o espaço de um conflito permanente entre os que pretendem concorrentemente determinar seu fundamento e conteúdo. Reflexo das lutas históricas, a identidade nacional é resultado de um trabalho em construção social que convém compreender, ao mesmo tempo, em sua estratégia e em sua dimensão cultural. ${ }^{20}$

20 DÉLOYE, Yves. Anação entre identidade e alteridade: fragmentos da identidade nacional. In: SEIXAS, Jacy A.; BRESCIANI, Maria S.; BREPOHL, Marion (Orgs.). Razão e paixão na política. Brasília: UNB, 2002. p. 95. 
Neste sentido, a identidade nacional ganha uma dinâmica pautada na construção de embates cotidianos e não apenas por meio da vontade/ imposição do Estado ou das elites. Para Déloye, a expressão identidade nacional já se faz complexa por sua própria polissemia, pois pode significar fronteira e clausura, que marcam as diferenças entre um país e outro, mas também unidade gerida pelo Estado. Essas concepções acabam por reafirmar o caráter excludente da identidade nacional e ainda a homogeneização dos indivíduos por meio da imposição cultural.

As reflexões do autor permitem construir uma noção de identidade nacional não como unidade de linguagem e raça, mas como sentimento de identificação, pois para ele: “A identidade francesa promovida não é resultado da inserção prévia do cidadão francês em uma etnia da qual ele herdaria a identidade, mas procede de um processo voluntário de identificação e orientação de sua ação". ${ }^{21}$

Para complementar a discussão sobre identidade nacional, as reflexões de Maria Stella Bresciani são luminosas. Em recente trabalho, a autora volta-se para a análise de como diferentes autores interpretaram o Brasil. Logo de início, Bresciani propõe-se revisitar autores esquecidos na historiografia, como Oliveira Viana e Paulo Prado, mais especificamente o primeiro. Percorrendo, assim, longo caminho, a autora busca desmistificar a tríade de intérpretes consagrados sobre o Brasil - Sérgio Buarque de Holanda, Caio Prado e Gilberto Freire -, criada involuntariamente por Antônio Candido em seu prefácio para o livro Raízes do Brasil.

Bresciani afirma que os autores nacionais criaram um lugar comum de interpretação sobre o Brasil, no qual entram em cena três explicações: o mito de origem, a importação de modelos interpretativos e a idéia de carência, de maneira sedutora e excludente de outras possibilidades, mantendo sua força até os dias atuais. Explicações essas que sempre recaem sobre uma única imagem: "a do país desencontrado consigo mesmo", ${ }^{22}$ com conotação ressentida e negativa. Com isso:

21 DÉLOYE, op. cit., p. 103.

22 BRESCIANI, Maria Stella. Identidades inclusas no Brasil do século XX - Fundamentos de um lugar comum. In: Ressentimentos e conformação de identidades; Identidade Nacional: uma questão sensível. In: O charme da ciência e a sedução da objetividade: Oliveira Viana interpreta o Brasil. Tese de titulamento apresentada ao Departamento de História/Unicamp, mimeo., 2003, p. 22. 
São imagens ressentidas e fortes: imagem de nação inconclusa e identidade ressentida, recalcada, frutos da incapacidade política de romper com a herança colonial ou de, tendo logrado um perfil autônomo no período colonial, ter se submetido a uma recolonização cultural por outros países europeus. ${ }^{23}$

Seguindo essa perspectiva de análise, a nação e a identidade de seus cidadãos não estavam prontas, mas sempre em construção, num eterno fazer-se. Esse discurso deu margem à criação do mito de que o passado colonial brasileiro gerou seu presente de atraso social e econômico, impedindo que o país conseguisse fortalecer-se como Nação autônoma. E, ainda por tal motivo, delega aos outros o papel de transformador da sociedade, elegendo o Estado (que se deseja forte) ou a elite política como porta-vozes dos mais variados anseios das diferentes classes sociais.

Contudo, e ainda de acordo com Bresciani, as transformações sociais continuam sonhadas para o futuro, pois não conseguem unir os anseios de todos, numa proposta comum, e assim: "Nossa identidade se constitui na falta, naquilo que não tivemos, na ausência de predicados, na incapacidade de triunfar. Há um vazio a ser preenchido, se possível for.”24

Bresciani, com sua questão central - "por que a identidade nacional se coloca como questão até os dias de hoje?” -, chama a atenção para a possibilidade de pensarmos o Brasil e sua identidade não a partir de suas carências, mas pelo olhar para dentro, no qual sejam respeitados os limites e principalmente a força de fazer-se como nação, problematizando a diferença, em vez de procurar similitudes. Trabalho difícil de se concretizar, uma vez que o país, ao não promover um rompimento definitivo com seus pais - Portugal - e sua dependência em relação aos países europeus, não consegue, com isso, delimitar seu terreno como nação forte. A perspectiva de análise de Bresciani revelou-se-nos como instigadora para um novo olhar sobre os vários sujeitos sociais da primeira República e os significados deles para a formação da identidade nacional.

Tendo essas referências é que nos propomos discutir a noção de identidade presente em alguns romances de Lima Barreto. Essa perspectiva de análise significa, em certa medida, pensar a formação da identidade na- 
cional e a inserção dos sujeitos marginais na política por um viés que não o usual, uma vez que se buscam as experiências cotidianas que não as consideradas como ideais pelos gestores da nação, mas sim recuperar as potencialidades e subjetividades dos sujeitos que estavam excluídos do processo de formação da identidade nacional.

Nas primeiras décadas republicanas no Brasil houve a construção de novos lugares sociais, nos quais é visível a exclusão da população economicamente mais pobre. Com a expulsão dos moradores pobres para os arredores da cidade, estes passam a viver na periferia, não só no que diz respeito ao espaço geográfico, mas também quanto a sua participação na política e na economia da sociedade brasileira.

Neste sentido, buscar os sentimentos, as sensibilidades e as novas relações experimentadas pelos variados tipos sociais que viviam a dinâmica conflituosa das primeiras décadas da República no Brasil torna-se complicado, pois compreender o significado de identidade para a população brasileira pobre que sofria com o crescente descaso do governo e a ditadura de uma elite conservadora requer entendimento amplo da realidade, que, por vezes, é contrária aos ideais democráticos.

Entendemos que a construção da identidade brasileira se fez por meio da diversidade de perfis e de experiências pertencentes tanto às elites quanto aos "marginais" da sociedade. Os últimos submetiam-se aos mais estranhos ofícios e passavam por fortes privações, mas nem por isso deixavam de existir/ resistir. Mesmo que de forma tímida, multiplicavam-se ações de contestação em prol de mudanças. Muitos desses cidadãos conseguiam melhores condições de vida, outros não. A instauração da República, inspirada em princípios democráticos, pressupunha a elevação de todos os cidadãos a um mesmo patamar de igualdade política, pois essa situação significava o primeiro passo para a constituição de uma nação moderna. No entanto, no Brasil, o:

caráter estreito, precavido e tardio dos atos com vistas a cumprir os requisitos das transições modernas, que implicam direitos de cidadania, induziu a criação de formas de subjetividade política afastadas tanto da referência concreta de um contrato social quanto da aspiração por uma cidadania autônoma. ${ }^{25}$

25 PAOLI, Maria Célia. Movimentos sociais, movimentos republicanos? In: SILVA, Fernando Teixeira; NAXARA, Márcia R.; CAMILLOT, Virgínia C. República, liberalismo, cidadania. Piracicaba: Unimepi, 2003. p. 164. 
As relações que se travam no Brasil demonstram a ineficiência desse contrato, uma vez que um dos contratantes, o povo, não era colocado na mesma condição - de igualdade - política que os sujeitos das elites econômicas e políticas. Com a República, delegou-se ao Estado a tarefa de elevar o povo à condição de cidadão, mas não se propiciou espaço para que todos atingissem a plena cidadania. Assim, criaram-se outras formas de identificação que muito se distanciam da referência primeira de igualdade de direitos mencionada pelo contrato republicano.

Esses sujeitos, de maneira particular, deixavam suas marcas pela cidade. Muitas vezes, suas ações cotidianas constituíam-se como uma afronta ao discurso civilizador que pregava uma cidade limpa e ordeira, tendo como inspiração o parâmetro burguês de conduta. Assim Barreto descreve esses cidadãos:

Fisionomias diferentes de trato e de cor: velhas de mantilha, moças de peito deprimido, barbudos portugueses de duros trabalhos, rostos de caixeiros, de condutores de bondes, de garçons de hotel e de botequim, mãos queimadas de cozinheiras de todas as cores, dedos gulhados de humildes lavadeiras (...). ${ }^{26}$

Para esses moradores da cidade, havia ainda uma infinidade de profissões que chamavam a atenção para uma realidade muito diversa da conhecida pela burguesia e que demonstravam a precariedade da vida dos sujeitos marginalizados, que, freqüentemente, eram omitidos nos discursos oficiais. Se não bastassem as diversidades fisionômicas, existia ainda uma variedade de profissões:

Além de serventes de repartições, contínuos de escritórios, podemos deparar com velhas fabricantes de rendas de bilros, compradores de garrafas vazias, castradores de gatos (...), mandingueiros, catadores de ervas, enfim, uma variedade de profissões miseráveis que a nossa pequena e grande burguesia não podem adivinhar. ${ }^{27}$

26 BARRETO, Lima. Clara dos Anjos. 5. ed. São Paulo: Ática, 1994. p. 114.

27 BARRETO, Lima. Triste fim de Policarpo Quaresma. In: HOUAISS, Antônio; NEGREIROS, Carmem Lúcia (Coords.). Edição crítica. Espanha: ALLCA XX, 1997. (Colección Archivos: 1ª, 30), p. 110. 
Há, então, para manutenção diária desses sujeitos, a invenção de postos de trabalhos marginais, que resultam numa módica remuneração. A realidade das experiências vivenciadas pelos sujeitos mais pobres era pouco conhecida pela burguesia, pois esta fazia questão de enxergar somente flores onde existiam muitos espinhos. Indo contra essa realidade, o ideal democrático das elites pregava um discurso de unidade republicana no qual todos estavam contemplados.

Contudo, baseando-nos no fato de que os sujeitos trazem em seu rosto as marcas da realidade em que vivem, as dificuldades e alegrias ficavam gravadas não apenas em suas recordações, mas também em seus traços, leveza ou aspereza de suas mãos, nos trajes usados no corpo, altivez e/ ou humildade diante da realidade que os maltratava, muitas eram as realidades experimentadas.

O personagem Isaías Caminha representa um exemplo esclarecedor dessa nova condição de cidadão gestada no Brasil. Caminha, tal como muitos outros cidadãos brasileiros, viu-se na condição de cidadão periférico, ou seja, os sem lugar na sociedade republicana. Sendo pobre, mulato e recém-chegado do interior ao Rio de Janeiro, o jovem moço se viu jogado na mais completa miséria, sem possibilidade imediata de transpor as barreiras do preconceito de cor e de posição social.

...e os meus sentimentos liberais que não podiam acusar o padeiro. Que diabo! eu oferecia-me, ele não queria! que havia nisso demais? /Era uma simples manifestação de um sentimento geral, e era contra esse sentimento, aos poucos descoberto por mim, que eu me revoltava. ${ }^{28}$

Esse cidadão periférico até poderia conseguir transpor as fortes barreiras impostas pela sociedade e, por isso mesmo, em algum momento, fazer parte da elite social. Mas a antiga situação na qual estava inserido não seria de todo esquecida, o que o faria se sentir estranho em sua própria terra, mesmo porque o espaço da ação desses sujeitos, na maioria das vezes restritos, inviabilizava a sua inserção em outros círculos de relacionamentos. Mas isto implicaria uma mudança radical de comportamento.

28 BARRETO, Lima. Recordações do escrivão Isaias Caminha. Rio de Janeiro: Ediouro; São Paulo: Biblioteca da Folha, 1997. p. 128. 
Queria-me um homem do mundo, sabendo jogar, vestir-se, beber, falar às mulheres; mas as sombras e as nuvens começam a invadir-me a alma, apesar daquela vida brilhante. Eu sentia bem o falso da minha posição, a minha exceção naquele mundo, sentia também que me parecia com nenhum outro, que não era capaz de me soldar a nenhum que desajeitado para me adaptar, era incapaz de tomar posição, importância e nome. ${ }^{29}$

As marcas impostas a esse cidadão da periferia rondavam os cantos da nova cidade, restringindo sua aceitação em vários ambientes. Assim, a democracia no Brasil, em seu começo, esteve em descompasso com a verdadeira realidade da maioria da população e mesmo dos ideais de igualdade política das sociedades modernas.

O acesso à educação trazia à tona mais uma dessas contradições. O discurso republicano pregava a educação como instrumento de formação dos cidadãos, sendo ela condição essencial para o progresso e desenvolvimento da cidadania. A monarquia havia-se esquecido da educação dos indivíduos menos favorecidos economicamente, mas os gestores republicanos proclamavam que agiriam diferente, dando ao povo a possibilidade de acesso ao ensino formal, "devolvendo-lhe” a condição de ser político. No entanto, as estatísticas mostram outra realidade:

O número de analfabetos no Brasil, em 1890, segundo a estatística oficial, era, em uma população de 14.333.915 habitantes, de 12.213.356, isto é, sabiam ler apenas 16 ou 17 em 100 habitantes do Brasil. Difícil será, entre os países presumidos de civilizados, encontrar tão alta proporção de iletrados. Assentado este fato, verifica-se logo que a literatura aqui falta a condição de cultura geral, ainda rudimentar e, igualmente o leitor consumidor dos seus produtos. ${ }^{30}$

Aliado à situação de poucos brasileiros terem a educação formal, havia ainda, na República, o difícil acesso aos livros, pois não se encontravam num templo acessível a qualquer um, independentemente de sua 
vestimenta, de seus trejeitos sociais, mas estavam restritos a uma pequena clientela, portadora de alto poder aquisitivo. Assim, se por um lado existia um discurso de ampliação do acesso à educação formal, por outro lado, as pessoas pobres que a desejassem passariam por sérios constrangimentos. Essa situação reforçava, portanto, a exclusão social. Afinal, os livros disponíveis acabavam sendo enclausurados pelo Estado em meio a uma série de etiquetas, pelas quais tornavam-se inacessíveis aos mais simples:

O Estado tem curiosas concepções, e esta de abrigar uma casa de instrução, destinada aos pobres-diabos, em um palácio intimidador, é das mais curiosas. (...) Como é que o Estado quer que os mal vestidos, os tristes, os que não têm livros caros, os maltrapilhos “fazedores de diamantes" avancem por escadarias suntuosas, para consultar uma obra rara. ${ }^{31}$

Dificultar o acesso ao saber era mais uma faceta da exclusão a que estavam sujeitos os mais pobres. Assim, na fala dos republicanos, os espaços e as oportunidades da cidade pareciam pertencer a todos; não se colocavam placas demarcatórias para a permissão da entrada dos indivíduos, mas o controle se dava de uma maneira mais sutil: por gestos, falas não pronunciadas num vazio de concreto e esplendor. Muitos sujeitos que não pertenciam a esse mundo de aparências, falas e gestos requintados se vêem excluídos desse local, perdidos em meio a um mar de etiquetas e regras a serem seguidas. "A minha alma é de bandido tímido, passando vejo desses monumentos, olho-os, talvez um pouco, como um burro; mas por cima de tudo, como uma pessoa que se estarrece de admiração diante de suntuosidade desnecessária”. ${ }^{32}$

Talvez a vergonha de não se sentir partícipe desse espaço público o impedia de ultrapassar as grandes escadarias da entrada suntuosa da Biblioteca Nacional e caminhar rumo ao monumento do saber, erguido pela República, ostentando toda sua pompa. Assim, dificilmente um cidadão mal trajado, não trazendo estampadas em seus gestos a ação, a fala e a aparência de pertencimento ao novo ideal de sociedade, adentraria os espa- 
ços requintados da Biblioteca Nacional, pois se perderia entre os vazios do novo prédio. Lima Barreto reafirma com isso uma certa nostalgia dos tempos passados, em que a "velha biblioteca era melhor, mais acessível, mais acolhedora, e não tinha a empáfia da atual”. ${ }^{33}$

Assim, por um lado, o discurso republicano utilizou-se do constrangimento para moldar esse cidadão periférico, demarcar seu espaço e fazê-lo comungar com uma realidade que não era sua. Por outro, existiam as elites que, lutando em favor do ideal de modernidade, expresso nas faces das damas da sociedade, dos cavalheiros, portavam-se com a finura que a situação demandava, fazendo-se visíveis nas ruas centrais da cidade carioca, em seus passeios rotineiros. Juntamente com os gestos e atitudes havia toda uma moral a ser seguida. De antemão, o trabalhador pobre era considerado como um ser indolente e preguiçoso.

Mas existem algumas singularidades nas imagens literárias que ainda podem ser exploradas para a construção da identidade do ser brasileiro. Para isso recorremos ao personagem Cassi Jones, na obra Clara dos Anjos. Na trama do romance, Jones é figura bastante emblemática, pois mesmo pertencendo a uma camada mais privilegiada do subúrbio mostrava-se avesso ao trabalho, e inventava outras formas para ganhar o dinheiro necessário para a satisfação de suas necessidades pessoais. Desde tenra idade, já havia mostrado inclinação para vadiagem, sempre aprontando diversas malandragens. Muito cedo foi expulso do colégio de padres. Passou toda a sua adolescência e juventude a praticar peraltices, a arrastar para a vergonha mulheres casadas e moças pobres - em sua maioria mulatas ou negras mas sempre teve a mãe como defensora de seus atos. Já o pai de Cassi acreditava que a única forma de corrigir acertadamente o filho seria "pô-lo numa oficina, a ver se o trabalho manual, já pelo cansaço, já pela convivência com pessoas honestas e de trabalho, desviava-o do mal caminho que ele estava iniciado." ${ }^{34}$

Logo em seu primeiro emprego Cassi foi despedido por roubo e não mais se preocupou em encontrar um trabalho diário. Para seu sustento, ocupava-se com galos de brigas. Mesmo sendo o dinheiro o seu ponto fraco, “queria-o, mas sem esforço”. A única atividade lucrativa à qual se dedi- 
cava era a briga de galo e outros jogos, sendo, então, visto como um típico vagabundo, pois "incapaz ao trabalho continuado":

Galos de briga era a força de sua indústria e do seu comércio equívocos. Às vezes ganhava bom dinheiro nas apostas de rinhadeiro, o que vinha ressarcir os prejuízos que porventura, anteriormente, houvesse tido nos dados; assim, conseguia meios para saldar o alfaiate ou comprar sapatos catitos e gravatas vistosas (...) Nunca suportara um emprego, e a deficiência de sua instrução impedia-o que obtivesse um de acordo com as pretensões de muita coisa que herdara da mãe; além disso, devido à sua educação solta, era incapaz para o trabalho assíduo, seguindo, incapacidade que, agora, roçava pela moléstia. A mórbida ternura da mãe por ele, a que não eram estranhas as suas vaidades pessoais, junto à indiferença desdenhosa do pai, com o tempo fizeram de Cassi o tipo mais completo de vagabundo doméstico que se pode imaginar. É um tipo bem brasileiro. $^{35}$

Cassi pode ser entendido como um cidadão às avessas, pois não se identificava ou era aceito por nenhum segmento social. Era considerado como marginal pela classe social "mais elitizada” e também pelos habitantes do subúrbio, pois todos respeitavam certas regras sociais. Suas relações de amizade estavam restritas a um pequeno número de indivíduos que, tal como ele, viviam de malandragens e roubos. Mas Cassi se faz diferente de todos, pois destacava-se entre seus companheiros pela esperteza, maneira de vestir-se e sua arte de tocar violão, e essa última o fazia aceito em muitas casas.

A trajetória desse personagem se faz interessante pois, mesmo sem se identificar com nenhuma das classes sociais que freqüentava, Cassi tinha trânsito livre em quase todas e nem sempre era apenas o algoz. Mesmo com a cumplicidade de sua mãe, ele é menosprezado pelo pai, que com o passar dos anos não lhe permite a entrada dentro da casa da família. Suas duas irmãs também não gostavam dele. Mas suas freqüentes conquistas permanecem impunes:

35 Ibid., p. 29. 
Até ali, ele contava com a benevolência secreta dos juízes e delegados, que, no íntimo, julgavam absurdo o casamento dele com as sua vítimas, devido à diferença de educação, de nascimento, de cor, instrução. Quanto à segunda e terceira causa, embora nem sempre se verifique a segunda, podia-se admitir; mas, quanto às duas outras considerações, eram errôneas, porque ele era tão ignorante e tão mal-educado como eram, em geral, as humildes raparigas que ele desgraçava irremediavelmente. / De resto, ele já não contava com proteção alguma. ${ }^{36}$

Na passagem acima tornam-se latentes vários privilégios que, tempos antes, os republicanos diziam querer liquidar. Esses privilégios conseguiam impor-se sobre o sofrimento das desonradas e seu futuro de misérias, libertando-o do casamento. Assim, mesmo Cassi sendo considerado um típico vagabundo, parte da sociedade (a mãe, os delegados e amigos) não lhe permitia o casamento com as vítimas de suas relações amorosas, por serem elas vistas como inferiores à sua condição social. Havia, então, na figura de Cassi Jones uma tensão constante, a qual não o enquadrava nem sempre no papel de vítima nem no de algoz.

Quando Cassi conhece Clara, uma linda mulata, a seduz com promessas de casamento e de uma vida feliz. Para a conquista de Clara, mesmo que não a amasse, não mediu esforços, chegando a matar Marranque, o padrinho da moça. Depois de concluída sua conquista e pressentindo complicações resolveu fugir, antes de descobrirem a gravidez de Clara. Cassi resolveu vender tudo o que possuía de valor, ou seja, seus galos, para, com o dinheiro, realizar sua fuga. Recebido o dinheiro, resolve colocá-lo no banco; para isso desce até a cidade. No caminho desiste, pois a qualquer momento poderia precisar do dinheiro e o banco poderia retardar sua fuga. Em sua caminhada encontra uma velha conhecida que, por alguns momentos, transforma o algoz em vítima:

- Então, você não me conhece mais, “seu canaia”? Então você não "si” lembra da Inês, aquela crioulinha que sua mãe criou e você... 
Lembrou-se, então, Cassi, de quem se tratava. Era a sua primeira vítima, que sua mãe, sem nenhuma consideração havia expulsado de casa, em adiantado estado de gravidez. Reconhecendo-a e se lembrando disso, Cassi quis fugir. A rapariga pegou-o pelo braço:

- Não fuja, não, "seu” patife! Você tem que "ouvi” uma "pouca” mas de "sustança".

A esse tempo, já os freqüentadores habituais do lugar tinham acorrido das tascas e hospedarias e formavam roda, em torno dos dois. (...)

-É sempre assim. Esses “nhonhôs gostosos” desgraçam a gente, deixam a gente com filho e vão-se. A mulher que se fomente ... Malvados!

Cassi ouvia tudo amarelo e olhava, por baixo das pálpebras, todas as faces daquele ajuntamento. Esperava a polícia, um socorro qualquer (...) Soltou uma inconveniência, acompanhada de um gesto despudorado, provocando uma gargalhada geral. Cassi continuava mudo, transido de medo (...) Graças à intervenção do dono da tasca, que tinha com a guarda de ronda o compromisso de manter a ordem no "reduto", o ajuntamento se desfez, e Cassi pôde continuar o seu caminho. Por despedida, porém, ainda levou uma surriada das mulheres, que o descompunham em baixo calão, enquanto Inês imprecava:

- “Marvado”! Desgraçado! Carcadura! Hás de “mi pagá”, “seu canaia”!

Logo que se viu longe do perigo, Cassi respirou, compôs a fisionomia, apalpou o dinheiro e fez de si pa si:

- Acontece cada uma! Para que havia dar esta negra (...) Felizmente, foi em lugar que ninguém me conhece; se fosse em outro qualquer - que escândalo! Os jornais noticiariam e (...) Não passo mais por ali e ela que fosse para o diabo!(...) Fico com o dinheiro em casa. ${ }^{37}$

Ao reencontrar sua primeira conquista, expulsa de casa pela mãe do rapaz ao descobrir a gravidez, Cassi recebe, mesmo que em pequena dose, o troco por suas malvadezas. A cena relatada demonstra no mutismo de Jones o medo; seu orgulho foi maculado perto de pessoas desconhecidas, pobres, sujeitos que em qualquer outra situação seriam menosprezados 
por Cassi. A revolta não era apenas de Inês, que por ele havia sido desgraçada, mas também de outras mulheres com a mesma sina. Assim, Cassi, que durante toda sua vida havia fugido da polícia, deseja por alguns momentos sua ajuda, coroando sua posição de vítima indefesa. Se em vários outros momentos de sua vida havia recebido a ajuda da mãe ou conhecidos, agora se vira só.

Há ainda expressa na passagem a preocupação de Cassi em manter uma postura de superioridade. O momento de franqueza da personagem só não foi mais desastroso porque não havia nenhum conhecido, fora a possibilidade do acontecido virar notícia de jornal, o que poderia trazer complicações ou mesmo impedi-lo de realizar seu plano de fuga. Interessante nesse acontecimento é pensar as várias situações com que Cassi se deparava no cotidiano. Nessas ocasiões nem sempre prevalecia uma situação de superioridade e arrogância perante suas vítimas.

Por meio da trajetória de Cassi Jones é possível detectar a possibilidade de um sujeito marginal se fazer visível em vários ambientes sociais, nos quais não existe apenas a figura do malandro, mas também de um sujeito que, ao ser "recebido" nesses espaços, utiliza-se das mais variadas artimanhas para construir seu cotidiano diferentemente das regras sociais a que esses marginais eram condicionados. Se sua postura num primeiro momento causa repulsa, em outros é possível vislumbrar um sujeito que, a seu modo, sai à procura de reconhecimento social. Seu modo de viver o faz marginal duplamente, mas nem por isso pode ser considerado apenas como um derrotado ou um "herói” que conquista todos os desejos, mas sim um homem que luta, ao seu modo, para construir uma forma de pertencer à sociedade que o rodeia.

Não somente pela figura de Cassi podemos perceber os marginais em busca de um viver diferente das regras impostas pelas elites. Em Lima Barreto é possível encontrar outras trajetórias de pessoas humildes que, em busca da sobrevivência, firmavam sua identidade em diferentes modos de vida. Exemplo disso é o caso da personagem do romance Clara dos Anjos, Margarida Weber, alemã, viúva, que para o sustento de sua casa e de seu único filho "Costurava para fora, bordava, criava galinhas, patos e perus, e mantinha-se serenamente honesta" ${ }^{38}$ 
Neste momento, havia na sociedade um espaço definido para as mulheres: o lar. Dona Margarida, ao ficar viúva, torna-se independente, sua honra está no fato de viver honestamente, conquistando uma condição de vida digna para si e seu filho. As relações de amizade dessa personagem são poucas e umas das mais próximas é Clara dos Anjos. A moça, ao descobrir sua gravidez, sai em busca da ajuda de dona Margarida. Esta, ao descobrir as intenções de aborto de Clara, conta para a mãe dela o que estava acontecendo. A mãe de Clara se desespera com a situação e se imobiliza, como sempre fazia nos momentos de pressão, pois não se considerava capaz de agir e decidir e, assim, sair da esfera da passividade. No entanto, a atitude de dona Margarida foi diferente, induzindo Clara a reivindicar o apoio da família do algoz. Cassi, nesse momento, já havia fugido.

A situação que se desenrola é muito interessante: mesmo que a sociedade acreditasse nas diferenças de cor e posição social como determinantes para a resolução dessas situações, essas duas figuras consideradas como marginais vão até o segmento social mais privilegiado buscar o que acreditavam ser seu de direito. Se para Clara o encontro por um lado foi frustrante, pois descobre a face mais preconceituosa da sociedade, por outro lado a motiva a fazer claras reflexões sobre a sociedade à qual pertence, não podendo ser, portanto, considerada como um ser sem ação, mesmo que esta seja limitada pelos preconceitos sociais.

O encontro entre a mãe de Cassi, Salustiana, e Clara revela a esta a triste realidade aceita pela sociedade:

Agora é que tinha noção exata de sua situação na sociedade. Fora preciso ser ofendida irremediavelmente nos seus melindres de solteira, ouvir desaforos da mãe de seu algoz, para se convencer de que ela não era uma moça como as outras; era muito menos no conceito de todos. Bem fazia adivinhar isso, seu padrinho! Coitado!.. / A educação que recebera, de mimos e vigilâncias, era errônea. Ela devia ter aprendido da boca de seus pais que a sua honestidade de moça e de mulher tinha todos por inimigos, mas isto ao vivo, com exemplos, claramente (...) O bonde vinha cheio. Olhou todos aqueles homens e mulheres... Não haveria um talvez, entre toda aquela gente de ambos os sexos, que não fosse indiferente à sua desgraça... Ora, uma mulatinha, filha de um carteiro! O que era preciso, tanto a ela como às suas iguais, era educar o caráter, revestir-se 
de vontade, como possuía essa varonil Dona Margarida, para se defender de Cassi e semelhante, bater-se contra todos que opusessem, por este ou aquele modo, contra a elevação dela, social e moralmente. Nada a fazia inferior às outras, senão o conceito geral e a covardia com aquelas que admitiam. ${ }^{40}$

A passagem, apesar de longa, traduz o despertar de Clara para a realidade das mulheres nas primeiras décadas republicanas, principalmente das mulatas e negras, sendo este um desabafo contra uma sociedade opressora, que não permitia o relacionamento entre pessoas de etnia e classificação social diferentes, mesmo que o elemento considerado bom (branco e com melhor posição social) fosse também um marginalizado como o era Cassi Jones. Aos olhos de Clara, dona Margarida se destacava pela sua postura perante a sociedade, pois não teme esses (pré-)conceitos sociais, mas busca o que acredita ser seu de direito; ela era, pois, uma pessoa de pulso.

Nesse processo de desnudamento da sociedade para Clara, tornase também interessante refletir sobre a força que a moça adquire. Ao contrário de se curvar a essas injustiças sociais, Clara pede por transformações no modo de agir e pensar da sociedade preconceituosa. Para ela, a ordem social vigente é equivocada, pois a sociedade mede as qualidades pessoais pela cor e posição social, mas ela acredita que mesmo sendo mulata e pobre isso não a faz diferente de ninguém. Mesmo num momento de profundo desalento com a sociedade e as regras sociais, Clara se faz mais forte do que elas.

A perspectiva de identidade que se percebe na reação de Clara não é a de derrota, mas de transformação/construção. Essas mudanças não partiriam de modelos internacionais importados, que muito se distanciavam da realidade brasileira, mas sim a partir da vivência desse sujeito marginal que encontrava em seu cotidiano as mais diferentes situações. Estas, por sua vez, não devem ser enclausuradas em tipos pré-concebidos, como, por exemplo, a figura do brasileiro como indolente, preguiçoso, mas pautada nas singularidades das vivências dos mais diversos cidadãos brasileiros que podem não estar trazendo nas faces ou nos gestos os indícios de 
pertencimento ao ideal de modernidade e de progresso sonhados pelas elites, mas experimentam em seu cotidiano diferentes formas de pertencer ao país chamado Brasil.

Por meio das ações realizadas pelos vários personagens de Lima Barreto é possível construir uma imagem menos limitada do ser brasileiro, e esta, mesmo que em alguns momentos considerada como marginal, busca, por meio de uma identificação com o cotidiano que lhe é imposto, construir uma nova noção de identidade. Noção essa pautada na busca incessante dos vários sujeitos pelo respeito à sua subjetividade. As ações desses cidadãos nem sempre foram tidas como vencedoras, ou mesmo recebidas pelas elites como forma de atuação social, mas nem por isso devem ser desconsideradas. Assim, acreditamos que o ser brasileiro foi construído tendo por base as mais diversas realidades e experiências encontradas no cotidiano de todos os cidadãos. 
